\title{
The Proper Use of Technologies as a Digital Citizenship Indicator: A Comparative Study of Two Universities in the Middle East
}

\author{
Dr. Mustafa Jwaifell \\ Associate professor in Department of Curriculum and Instruction \\ Faculty of Educational Sciences, Al-Hussein Bin Talal University \\ PO box 20, Ma'an, Hashemite Kingdom of Jordan \\ Tel: 9-626-775-620480 E-mail: jwaifell@hotmail.com \\ Dr. Buad Alkhales \\ Associate professor in Department of primary and kindergarten \\ Faculty of Educational Sciences, Al-Quds University \\ PO box 20002, Al-Quds, Palestine \\ Tel: 0526994885 E-mail: buad2016@gmail.com
}

Received: Dec. 12, 2018 Accepted: Jan. 4, 2019 Published: February 1, 2019

doi:10.5296/jse.v9i1.14079 URL: https://doi.org/10.5296/jse.v9i1.14079

\begin{abstract}
The paper compares students' proper use of technology as a digital citizenship indicator between both of Al-Hussein Bin Talal University (AHU) in Jordan and Al-Quds University in Palestine territory and, Digital citizenship with its nine elements: Etiquette, Communication, Education, Access, Commerce, Responsibility, Rights, Safety, and Security are connected to all life aspects. It is hard to ignore the increasing misuse phenomenon of the emerging technologies. This paper shed the light on how the students in both universities campuses use technologies in a citizenship manner. A measurement tool worked as a test to reveal students technology usage as an indicator of their digital citizenship. Results of the study revealed that students in both universities do not properly use technologies as a digital citizenship indicator and there are differences among the two countries. The study included recommendations to overcome technology usage within university campus.
\end{abstract}

Keywords: digital citizenship, technologies, Jordanian university students, Class teacher students, Palestine and Jordan. 


\section{Introduction}

Technology is widely used in the Arab world among all levels of school and university students. Yet, there isn't real evidence about technology misuse within university students, which may lead to a major problem. Most students in Jordanian and Palestine territory universities own and use technology such as computers and smart mobile phones and have the same social and cultural biases beside they are neighbors. Thus, they can use those technologies -as hypnotized- appropriately to access on-line resources for information which enhances their learning process. However, it requires full understanding of technology and how to use it.

\section{Background of the study}

Having the sense of being part of the community is referred to citizenship (Bosniak, 2006); citizenship is achieved when individuals respond to their community. Emotional and active engagement with the individuals' own community can be a product of citizenship and the idea of citizenship indicates that individual duties and rights are restricted to their local community since it has been limited by particular territories.

Citizenship concept contributes to the understanding of how citizenships is formed at certain places, and it is important to notice that being an active citizen in your local community is commonly defined by residency (Villazor, 2009). When local residents cooperate with each other and form localized social networks, this leads to strengthening the understanding of citizenship as they work on common responsibilities for their community benefit (Mason, 2009). Therefore a collective sense of responsibility is created when having common interests produced from the social networks for those residents. (Bell, 1998; Kasarda \& Janowitz, 1974; Ryan et al, 2005; Jwaifell, M., Abu-Omar, A., \& Al-Tarawneh, M. 2018).

Citizenship can be defined as democratic participation practice. It is a fundamental point to explain how individuals involve themselves in their local communities' political life. Citizenship requires commitment of the citizen towards the community (Falk, 1994). The residents of any community show higher engagement in local activities if they are strongly committed to their community (McLeod et al., 1996; Steinberger, 1984), where usually residents' commitment is achieved by shared community-level experiences. While citizenship models, help us understand the abstract concept of citizenship through finding out which civic ideas or behaviors are grouped together, and how they are explained. Citizenship models have descriptive and normative aspects just like theories, in terms of its descriptive aspect, the models gather facts and assumptions, yet these facts are always closely connected to normative assumptions. Besides citizenship models are highly normative and have political power. Different democratic theories set different models of good citizenship while citizenship models help determine which behaviors will be valued (Vilenchik, 2017).

Digital media may help shifting the traditional citizenship concept from physical community into virtual community where people meet over the internet and engage in civic actions (Bimber, 2012; Cammaerts \& Van Audenhove, 2008; Gruzd, Takhteyev, \& Wellman, 2011; Wellman et al., 2001). The worldwide expansion of social networks has produced a new form 
of social ties (O'Byrne, 2003). Engagement in virtual communities of individuals and organizations that are based on common interests produces a sense of commitment. This is applied on recent cases of global protests that were based on digital media, especially social media that contributed in creating a strong sense of community and cooperative work (Enjolras et al., 2013, p. 900). Citizenship can be defined as democratic participation practice. On the other hand, digital media encourages individual engagement in online communities that are based on common concerns; individuals have a better chance to realize their duties or responsibilities towards communities outside their local communities, considering this as one of the fundamental actions for the civil society.

\section{Digital Citizenship}

Vilenchik and Thorson (2015) highlighted that good citizenship is always presented as a fixed clear standard, it is also described as digital citizenship for social construction that became a crucial concept for tying internet usage with the ability in participation in the virtual community (Buente, 2015). Citizenship is an online world that concerns to the role of political information and participation, in order to fill the democratic gap; individuals can obtain political information online" (Min, 2010; Nam \& Stromer-Galley, 2012; Norris, 2001).

Digital citizenship is one possible way that helps explore the ways the internet participates in citizenship. In 2002, Shulman et al. decided that unequal levels of information technology literacy form a significant obstacle for citizenship. Digital citizenship is important for providing equal chances for citizens in reaching a wide electronic interface with the government, as argued by Shelley et al. Shelley et al observed that socio structural factors such as income and education were significant barriers to digital citizenship, as they prevented internet users from becoming digital citizens. (Shelley et al., 2006; Thrane, Shelley, Shulman, Beisser, \& Larson, 2005). Other barriers to digital citizenship are inequalities related to the access and use of ICTs as argued by Mossberger et al.in 2007.

In defining digital citizenship as "the norms of behavior for technology use" (Ribble \&Bailey, 2006. 28), digital citizenship can be described as involving "appropriate technology usage," and "making safe, responsible, respectful choices online, thus digital citizenship education is very essential to be shifted from digital literacy education (Internet and computer technical skills) to a manner of proper use. Many in the field already use the term 'digital literacy' to refer to computer and Internet-based skills such as knowing good search strategies, understanding and using privacy settings, practicing identity theft protection behaviors, creating safe passwords, correctly, citing online information, and avoiding spam and e-scams (Koltay, 2011). Digital literacy requires a very specific set of educator knowledge and teaching skills compared to other goals currently under the digital citizenship umbrella. (Jones and Mitchell, 2016).

\subsection{Digital citizenship Elements}

Digital citizenship consisted of nine elements (ISTE, 2011): digital access, commerce, communication, literacy, etiquette, law, rights and responsibilities, health and wellness, and security. 
Element 1: Digital Access: which can be defined as full electronic engagement in society, where a large number of people can communicate with each other using social media.

Element 2: Digital Commerce: This is the act of buying and selling goods online. Now a day, many people including youths sell and buy through the Internet especially in Jordan where buying through Facebook became very popular. So Learning to become an intelligent consumer is an important indicator of good citizenship.

Element 3: Digital Communication: exchanging knowledge and information electronically. This manner is very important especially in Arab Spring era, where spreading wrong information can lead to misguiding youths, Therefore youth may interact with ones who have a private agenda that doesn't serve humanity such as terrorist organizations or people who attend to communicate with others under abuse intention.

Element 4: Digital Literacy: knowing about technology and its use. For example, Jordan started to educate youths about new technology and how to use it as a resource of information which is very obvious in all curricula activates but not in a direct and organize way, while Bani Abdelrahman, Jwaifell \& El-Subhieen, (2014) investigated information literacy among the students in Jordan, their study results pointed that information skills are not mastered by AHU students.

Element 5: Digital Etiquette: main concern of this aspect is electronic standards of conduct or procedure. Students should learn that the use of technology is not how others use it rather than using it in appropriate manner.

Element 6: Digital Law: electronic responsibility for actions and deeds. Students should be aware of legal and illegal use of information available on the Internet, where technology made it very easy to upload, download, locate and access information, so it is very important to distinguish between what is legal and what is not beside the intellectual property and authoring ethics.

Element 7: Digital Rights and Responsibilities: rights and responsibilities are the requirements and freedoms extended to all users in digital world. Digital societies have their own rules, and all expect that any member should be committed to those rules and ethics and accepting group policies, even the protection groups give.

Element 8: Digital Health and Wellness: physical and psychological well-being within digital technology. Internet addiction is one of psychological danger students may face, while body injury such as neck's vertebra and carpal tunnel syndrome.

Element 9: digital Security: software and hardware protections. Protecting personal data from violating it by viruses as a digital crime for instant is the main aspect of this element, where students should be educated about protecting their data, files and any software in addition to procedures on how to protect themselves from hackers attacks.

Ribble \&Bailey (2006) resembled nine elements of digital citizenship in a form of a quiz including nine questions and statements with four multiple choices, the nine elements were: Digital Etiquette (Manners), Digital Communication (Messages), Digital Education 
(Learning), Digital Access (inclusion), Digital Commerce (Business), Digital Responsibility (Trust), Digital Rights (Privileges), Digital Safety (Protection), and Digital Security (Self-Protection). Items of the quiz are formed as questions or statements with one right answer as shown in Appendix 1 after modifying items for university students.

\section{Related studies}

Currently, few research studies have been conducted on investigating the use of technologies as a digital citizenship indicator. Studies in Jordan for instance investigated the use of technology among university students (Jwaifell, M., Al-Shalabi, H., Andraws, S., Awajan, A., \& Alrabea, A. 2013; Swidan, A., Al-Shalabi, H., Jwaifell, M., Awajan, A., \& Alrabea, A. 2013; Nassar, I. A, Hayajneh, J. A, \& Almsafir, M. K. H. 2013). It also has been concluded that there is a relationship between digital citizenship and information literacy in using the internet (Al-Atyat \& Jwaifell. 2014).

To our best knowledge, there is one specific study in Jordan that has been conducted to investigate the students' digital citizenship in a form of a test survey by Jwaifell (2018) for investigating the technology usage as a digital citizenship indicator among undergraduate English language students at Al-Hussein Bin Talal University (AHU) where the study revealed that students do not properly use technologies as a digital citizenship indicator. Another study was conducted in Jordan aimed to identify the degree of embedding digital citizenship concepts within national and civic educational textbooks which is Tawalbe (2017) study, the study sample consisted of (43) teachers and adopted structured interviews and content analysis of all collected surveyed data where results revealed an absence of the use of the term digital citizenship in all national and civic textbooks, and they were free of any occurrence of (63) concepts.

Meanwhile there are few globally conducted studies: d'Haenens, Koeman \& Saeys (2007) investigated the digital citizenship among ethnic minority youths in Netherlands and Flanders. The study sample consisted of six different ethnics: Flemish Turks, Dutch Turk, Flemish Moroccans, Native Flemish and Native Dutch. The tool of the study was a questionnaire distributed for gathering data. The research dealt with five distinguished types of digital citizens: e-communicating, e-democratic, e-surfing, e-working and e-consuming. The study concluded that ethnics could emerge different uses of ICT, like gender for instance; as Moroccan girls communicate only with their relatives and other ethnics from the same gender. The study concluded that using ICT may lead to bridge the gap between cultures rapidly and can work as an indicator for being citizens in a form of e-citizenship.

Social network sites can be considered as the most suitable environment to establish a digital community; therefore it may provide a rich field for studying digital citizenship. Lenhart, Madden, Smith, Purcell, Zickuhr \& Raninie (2011) explored how American teens navigate the new world of digital citizenship. The findings of the study revealed that teens witnessed cruelty, negative outcomes and harassment.

Dillinger (2015) explored in her thesis resources and standards available to educators to help implement digital citizenship into the curriculum on how to enhance classroom lessons with 
digital citizenship skills where technology is used. The results of her study demonstrated the need to incorporate digital citizenship skills into school lessons in order to teach students independent and responsible online behavior.

\section{Purpose of the Study}

Based on Jwaifell (2018) study, this study was conducted under the claim that better technologies usage works as an indicator of digital citizenship. Therefore, this study is aimed at investigating the technology usage as a digital citizenship indicator among undergraduate's class teacher students at both of Al-Hussein Bin Talal University (AHU) in Jordan and Al-Quds University in Palatine territory, by answering the following questions:

Q1: Do undergraduate's class teacher students at AHU in Jordan and Al-Quds University use technologies properly as a digital citizenship indicator?

Q2: Do AHU and Al-Quds university undergraduate's class teacher students differ in using technologies properly as a digital citizenship indicator?

\section{Methodology}

The primary purpose of this study was to quantitatively compare students' proper use of technology as a digital citizenship indicator between both of AHU and Al-Quds universities, therefore, the descriptive method was used in the study design and he researchers conducted the survey through a measurement tool as a mean of collecting data on the proper use of technology as a digital citizenship.

\subsection{Setting and Participants}

The participants of this study consisted of voluntary (188) undergraduate's class teacher students at both AHU in Jordan and Al-Quds University in Palestine as shown in Table 1:

Table 1. The Participants of the Study

\begin{tabular}{|l|l|l|l|}
\hline University & Male & Female & Total \\
\hline AHU & 18 & 96 & 114 \\
\hline Al-Quds & 17 & 57 & 74 \\
\hline Total & 35 & 153 & 188 \\
\hline
\end{tabular}

The researchers main concern committed to measure the technology usage as a digital citizenship indicator among undergraduate's class teacher students as a comparison between both of AHU university in Jordan and Al-Quds university in Palestine, in order to understand the whole picture of their usage of technologies as a digital citizenship indicator and give recommendations to the administrations of both universities and academic staff for better understanding when planning to the use of technologies and the Internet.

\subsection{The Measurement Tool}

The study modified the items of instrument based on Ribble \&Bailey (2006). While analyzing the items content, it appears to the researchers and the 6 referees who validated the 
quiz, that those items does not have any cultural biases and commonly applicable to the undergraduate's class teacher students at both universities AHU/Jordan and Al-Quds/Palestine within Middle Eastern context, while the quiz items designed for all K-12 levels students, the referees pointed that the quiz after modification is suitable for University students (see table1). The modified quiz reliability was calculated by (25) students out of the study sample but drawn from the population itself, where Pearson Correlation $=0.86$ which is significant at the 0.01 level.

\section{Findings and Discussion:}

The Analysis of the resulting data was performed using descriptive statistics. Descriptive measures including means, standard deviations and frequencies of Right Answer (R.A) and Wrong Answer (W.A) for proper use of technologies as a digital citizenship indicator used to answer the questions of the study; these descriptive statistical measures were also tabulated and reported for classifying variable of University students are related to; in order to determine students' proper use of technologies as a digital citizenship indicator as shown in the following table:

Table 2. Answers of the Quiz

\begin{tabular}{|c|c|c|c|c|c|c|c|c|c|}
\hline \multirow{2}{*}{ Elements } & \multicolumn{3}{|c|}{$\mathrm{AHU}$} & \multicolumn{3}{|c|}{ Al-Quds } & \multicolumn{3}{|l|}{ Total } \\
\hline & W.A & R.A & R.A\% & W.A & R.A & R.A \% & W.A & R.A & R.A \% \\
\hline Digital Etiquette & 80 & 34 & 30 & 47 & 27 & 36 & 127 & 61 & 32 \\
\hline Digital Communication & 35 & 79 & 69 & 31 & 43 & 58 & 66 & 122 & 65 \\
\hline Digital Education & 102 & 12 & 11 & 62 & 12 & 16 & 164 & 24 & 13 \\
\hline Digital Access & 101 & 13 & 11 & 68 & 6 & 8 & 169 & 19 & 10 \\
\hline Digital Commerce & 32 & 82 & 72 & 12 & 62 & 84 & 44 & 144 & 77 \\
\hline Digital Responsibility & 92 & 22 & 19 & 38 & 36 & 49 & 130 & 58 & 31 \\
\hline Digital Rights & 63 & 51 & 45 & 40 & 34 & 46 & 103 & 85 & 45 \\
\hline Digital Safety & 93 & 21 & 18 & 63 & 11 & 15 & 156 & 32 & 17 \\
\hline Digital Security & 65 & 49 & 43 & 37 & 37 & 50 & 102 & 86 & 46 \\
\hline Total & 663 & 363 & 35 & 398 & 268 & 40 & 1061 & 631 & 37 \\
\hline
\end{tabular}

W.R=Wrong Answer, R.A=Right Answer

Results of Q1: Do undergraduate's class teacher students at AHU in Jordan and Al-Quds University use technologies properly as a digital citizenship indicator? 
Taple 2 showed answers of AHU students for the quiz questions and statements, it appears that:

1. Digital Education is the most improper use of technologies as a digital citizenship indicator where only (12) students out of (114) chose the right answer with (11\%). As an indicator showing that students do not know the different technologies are and how they are used within the campus of the university. When comparing this result with Al-Quds University students, it appeared that (12) of Al-Quds chose the right answer with (16\%) of the total which led to the same result as AHU University students' improper use.

2. Digital Access is used improperly in both universities, with (11\%) for AHU and (8\%) of Al-Quds students. This result shows that students of both universities think that ones who have learning disabilities should not have the same opportunities as others in using technology, which can be referred to students' lack of knowledge about technology tools that can be accommodated to overcome students disabilities.

3. Elements of digital citizenship are equal or less than $(50 \%)$ reached the right answer in both universities, where:

a) Digital Etiquette in AHU (30\%); Al Quds (36\%) only chose the right answer, which means that both universities students do not turn of their cell phones within the university campus and do not care of disturbing others,

b) Digital Responsibility in AHU (19\%); Al-Quds (49\%) chose the right answer, which means that both universities students do not give credit to the author of the information when using graphics and texts from the Internet,

c) Digital Rights in AHU (45\%); Al-Quds (46\%) indicated that both of the universities students do not know about the privileges of other authorities,

d) Digital Safety in AHU (18\%); Al-Quds (15\%) only care about physical health when using technology, which means that (82\%) of AHU students and (75\%) of Al-Quds students are using technology improperly, and

e) Digital Security in AHU (43\%); Al-Quds (50\%) is not used in a proper way, which means $(57 \%)$ of AHU students give personal information about themselves to anonymous persons online.

4. Element of digital citizenship are more than $(50 \%)$ reached the right answer in both universities, where: Digital Communication in AHU (69\%); Al-Quds (58\%) of the participants use technology properly, where they only add friends and family members in their Buddy list to communicate with. This result can be referred to cultural bias and religion of community those students refer to., and Digital Commerce in AHU (72\%); Al-Quds (84\%) are using technology properly, where they check to see if the site is safe and secure If they want to buy things online.

5. The total of the Digital Citizenship was improper, where AHU (35\%) and Al-Quds (40\%) only chose the right answer, and (73\%) of the participants chose the wrong answer, which can 
be an indicator of poor citizenship in both universities and students are using technology improperly.

Those results indicated that:

1. Students have to be educated more about manner of using digital devices within the university campus, where only $32 \%$ of them know and practice digital etiquette.

2. Digital communication were used in a prober way, while $(65 \%)$ of the students confirmed the right answer: communicating with close friends and family members. In Arab culture, parents monitor their children's devices used in communication with others beside the way they educate their children in a religious manner.

3. Digital education with (30\%) of right answer about how to choose the right technology for learning, which indicates the need to more educating students about how to choose the right technologies for learning use within the university.

4. All the other elements: digital access, responsibility, rights, safety and security are not known very well for most of the students, which reveals the lack of training and supervision. The Arab people usually deal with trust in their ordinal life, they were not raised with mistrust, and this explains their wrong answers.

\section{Results of Q2: Do AHU and Al-Quds university undergraduate's class teacher students differ in using technologies properly as a digital citizenship indicator?}

To answer the second question, frequencies were calculated and tabulated as shown in Table4, the Chi Square was used to examine the distributions of AHU/Al-Quds Universities' R.As and W.As at sig. 2-sided $(\alpha \leq 0.05)$ as shown in the following table: 
Table 3. Male/Female Answers and Chi Square Results

\begin{tabular}{|c|c|c|c|c|c|c|c|}
\hline \multirow{3}{*}{ Elements } & \multirow{3}{*}{ No } & \multicolumn{4}{|c|}{ University } & \multirow{3}{*}{$\begin{array}{l}\text { Chi } \\
\text { Square }\end{array}$} & \multirow{3}{*}{$\begin{array}{l}\text { Sig } \\
\text { (2-sided) }\end{array}$} \\
\hline & & \multicolumn{2}{|l|}{ AHU } & \multicolumn{2}{|c|}{ Al-Quds } & & \\
\hline & & R.A & W.A & R.A & W.A & & \\
\hline Digital Etiquette & $\begin{array}{l}\text { Observed } \\
\text { Expected }\end{array}$ & $\begin{array}{l}34 \\
37\end{array}$ & $\begin{array}{l}80 \\
77\end{array}$ & $\begin{array}{l}27 \\
24\end{array}$ & $\begin{array}{l}47 \\
50\end{array}$ & 0.909 & 0.34 \\
\hline $\begin{array}{l}\text { Digital } \\
\text { Communication }\end{array}$ & $\begin{array}{l}\text { Observed } \\
\text { Expected }\end{array}$ & $\begin{array}{l}79 \\
74\end{array}$ & $\begin{array}{l}35 \\
40\end{array}$ & $\begin{array}{l}43 \\
48\end{array}$ & $\begin{array}{l}31 \\
26\end{array}$ & 2.466 & 0.116 \\
\hline Digital Education & $\begin{array}{l}\text { Observed } \\
\text { Expected }\end{array}$ & $\begin{array}{l}12 \\
14.6\end{array}$ & $\begin{array}{l}102 \\
99.4\end{array}$ & $\begin{array}{l}12 \\
9.4\end{array}$ & $\begin{array}{l}62 \\
64.6\end{array}$ & 1.305 & 0.253 \\
\hline Digital Access & $\begin{array}{l}\text { Observed } \\
\text { Expected }\end{array}$ & $\begin{array}{l}13 \\
11.53\end{array}$ & $\begin{array}{l}101 \\
102.5\end{array}$ & $\begin{array}{l}6 \\
7.5\end{array}$ & $\begin{array}{l}68 \\
66.5\end{array}$ & 0.536 & 0.464 \\
\hline Digital Commerce & $\begin{array}{l}\text { Observed } \\
\text { Expected }\end{array}$ & $\begin{array}{l}82 \\
87.3\end{array}$ & $\begin{array}{l}32 \\
26.7\end{array}$ & $\begin{array}{l}62 \\
56.7\end{array}$ & $\begin{array}{l}12 \\
17.3\end{array}$ & 3.517 & 0.061 \\
\hline Digital Responsibility & $\begin{array}{l}\text { Observed } \\
\text { Expected }\end{array}$ & $\begin{array}{l}22 \\
35.2\end{array}$ & $\begin{array}{l}92 \\
78.8\end{array}$ & $\begin{array}{l}36 \\
22.8\end{array}$ & $\begin{array}{l}38 \\
51.2\end{array}$ & 18.12 & 0.000 \\
\hline Digital Rights & $\begin{array}{l}\text { Observed } \\
\text { Expected }\end{array}$ & $\begin{array}{l}51 \\
51.5\end{array}$ & $\begin{array}{l}63 \\
62.5\end{array}$ & $\begin{array}{l}34 \\
33.5\end{array}$ & $\begin{array}{l}40 \\
40.5\end{array}$ & 0.026 & 0.871 \\
\hline Digital Safety & $\begin{array}{l}\text { Observed } \\
\text { Expected }\end{array}$ & $\begin{array}{l}21 \\
19.4\end{array}$ & $\begin{array}{l}93 \\
94.6\end{array}$ & $\begin{array}{l}11 \\
12.6\end{array}$ & $\begin{array}{l}63 \\
61.4\end{array}$ & 0.402 & 0.526 \\
\hline Digital Security & $\begin{array}{l}\text { Observed } \\
\text { Expected }\end{array}$ & $\begin{array}{l}49 \\
52.1\end{array}$ & $\begin{array}{l}65 \\
61.9\end{array}$ & $\begin{array}{l}37 \\
33.9\end{array}$ & $\begin{array}{l}37 \\
40.1\end{array}$ & 0.890 & 0.345 \\
\hline Total & $\begin{array}{l}\text { Observed } \\
\text { Expected }\end{array}$ & $\begin{array}{l}363 \\
382.6\end{array}$ & $\begin{array}{l}663 \\
643.4\end{array}$ & $\begin{array}{l}268 \\
248.4\end{array}$ & $\begin{array}{l}398 \\
417.6\end{array}$ & 4.079 & 0.043 \\
\hline
\end{tabular}


Results of Chi Square showed no statistical significance differences between of AHU and Al-Quds' distributions for the proper use of technologies as a digital citizenship indicator of undergraduate's class teacher students at AHU in Jordan and Al-Quds Universities, except the digital responsibility element and the total result of all elements was that AQU students use technology properly.

These results can be explained in a manner of similarity between the two countries, while the difference at the total of proper use of technology and Digital responsibility can be related to the number of the participants in both universities, where AQU students sample is smaller than AHU students sample, therefore the measurement error can be very high.

\section{Conclusion}

The study revealed that undergraduate's class teacher students at Al-Hussein Bin Talal University (AHU) in Jordan and Al-Quds University students do not use technologies as a digital citizenship indicator properly. Technologies are not new to youths in Jordan and Palestine, they use smart mobile phones and computers for more than two decades, but it seems that policy makers in both ministry of education and higher education in both countries relay on parents more than curricula. Out of these study findings, it is very essential to elaborate efforts in both schools and universities to bridge the gap between technologies as a life tool and as an academic proper usage tool, thus, this study turns the light on having more responsibilities for educating youths on how to learn about technologies and concept of citizenship.

\section{References}

Abu-Omar, Rima, \& Jwaifell, Mustafa. (2018). Digital Citizenship in the Arabic Language Textbooks: Content Analysis. Journal of Education and Practice, 9(32), 47-63.

Al-Atyat, Khalid., \& Jwaifell, Mustafa. (2014). Information Literacy among Jordanian Teachers: Case of Madaba. Journal of Education and Practice, 5(28), 102-111.

Al Doghmi, Atika., Al-Shalabi, Hasan., Jwaifell, Mustafa, Andraws, Swidan., Awajan, Arafat., \& Alrabea, A. Ilrabea. (2013). The academic use of social networks among university students in Jordan. International Journal of Computer Science Issues, 10(5), 134-141.

Bani Abdelrahman, Mahmoud., Jwaifell, Mustafa., \& Eed, El-Subhieen. (2014). Information Literacy: Study of Incoming First-year Undergraduates Students who major in English Language at Al- Hussein Bin Talal University. Journal of Education and Practice, 5(18), 152-167.

Bell, Michael. (1998). The Dialogue of Solidarities, or Why the Lion Spared Androcles. Sociological Focus, 31(2), 181-199. https://doi.org/10.1080/00380237.1998.10571100

Bimber, Bruce. (2012). Digital media and citizenship. In H. A. Semetko \& S. Margaret (Eds.), The SAGE handbook of political communication (pp. 115-126). Thousand Oaks, CA: Sage. http://dx.doi.org/10.4135/9781446201015.n10.

Bosniac, Linda. (2006). The Citizen and the Alien. Dilemmas of Contemporary Membership, 
Princeton Unversity Press. https://doi.org/10.1515/9781400827510

Buente, Wayne. (2015). Digital Citizenship or Inequality? Linking Internet Use and Education to Electoral Engagement in the 2008 U.S. Presidential Election Campaign. Bulletin of Science, Technology \& Society, 35(5-6), 145-157. https://doi.org/10.1177/0270467615624756

Cammaerts, Bart., \& Van Audenhove, L. (2008). Online political debate, unbounded citizenship, and the problematic nature of a transnational public sphere. Political Communication, 22(2), 179-196. https://doi.org/10.1080/10584600590933188

d'Haenens, Leen., Koeman, Joyce., \& Saeys, Freida. (2007). Digital citizenship among ethnic minority youths in the Netherlands and Flanders. New Media \& Society, 9(2), 278. https://doi.org/10.1177/1461444807075013

Dillinger, Annette. (2015). Digital Citizenship and Today's Online Students (Unpublished Theses University of Central Missouri). Available at: http://centralspace.ucmo.edu/bitstream/handle/123456789/438/Dillinger_LIBRARY.pdf?sequ ence $=1 \&$ is Allowed $=\mathrm{y}$.

Enjolras, Bernard., Steen-Johnsen, Kari., \& Wollebaek, Dag. (2013). Social Media and Mobilization to Offline Demonstrations: Transcending Participatory Divides? New Media \& Society, 15(6), 890-908. https://doi.org/10.1177/1461444812462844

Falk, Richard. (1994). The making of global citizenship. In B. Steenbergen (Ed.), The condition of citizenship (pp. 127-140). Thousand Oaks, CA: Sage. https://doi.org/10.4135/9781446250600.n10

Fonseca, Clotide., \& Bujanda, Mugenia. (2011). Promoting Children's Capacities for Active and Deliberative Citizenship with Digital Technologies: The CADE Project in Costa Rica. The Annals of The American Academy of Political and Social Science. 622(1), 243-262. https://doi.org/10.1177/0002716210383657

Gruzd, Anatoliy., Wellman, Barry., \& Takhteyev, Yuri. (2011). Imagining Twitter as an Imagined Community. American Behavioral Scientist, 55(10), 1294-1318. https://doi.org/10.1177/0002764211409378.

ISTE (2011). Digital citizenship in schools. Retrieved from: http://www.iste.org/docs/excerpts/DIGCI2-excerpt. Pdf.

Jones, Lisa., \& Mitchell, Kimberly. (2016). Defining and measuring youth digital citizenship, new media \& society, 18(9), 2063-2079. https://doi.org/10.1177/1461444815577797

Jwaifell, Mustafa. (2018). The Proper Use of Technologies as a Digital Citizenship Indicator: Undergraduate English Language Students at Al-Hussein Bin Talal University. World Journal of Education, 8(3), 86-94. https://doi.org/10.5430/wje.v8n3p86

Jwaifell, Mustafa. (2015). Teachers' Perceptions of Web Quest as Effective Teaching. International Journal of Science: Basic and Applied Research, 22(1), 165-171. 
Jwaifell, Mustafa., Abu-Omar, Reema., \& Al-Tarawneh, Mohammad. (2018). The Readiness of Arabic Language Teachers for Integrating Flipped Classroom: Case of Ma'an. International Journal of Instruction, 11(4), 855-868. https://doi.org/10.12973/iji.2018.11454a

Jwaifell, Mustafa., Al-Shalabi, Hasan., Andraws, Swidan., Awajan, Aarafat., \& Alrabea. (2013). The intensity of social networks group use among the students of Jordanian universities. Global Journal of Computer Science and Technology Network, Web \& Security, 13(2), 1-8.

Kasarda, John., \& Janowitz, Morris. (1974). Community attachment in mass society. American Sociological Review, 39(3), 328-339. https://doi.org/10.2307/2094293

Koltay Tibor (2011) The media and the literacies: media literacy, information literacy, digital literacy. Media, Culture \& Society, 33(2), 211-221. https://doi.org/10.1177/0163443710393382

Lenhart Amanda, Madden Mary, Smith Aaron, Purcell Kristen, Zickuhr Kathryn \& Rainie Lee. (2011) Teens, Kindness and Cruelty on Social Network Sites. Washington, DC: Pew Internet and American Life 2011. [2015-08-21]. http://www.pewinternet.org/2011/11/09/teens-kindness-and-cruelty-on-socialnetwork-sites/

McLeod, Jack., Daily, Katie., Guo, Zhongshi., Eveland, William., Bayer, Jan., Yang, Seungchan., \& Wang, Hsu. (1996). Community integration, local media use, and democratic processes. Communication Research, 23(2), 179-209. https://doi.org/10.1177/009365096023002002

Min, Seong-Jae. (2010). From the digital divide to the democratic divide: Internet skills, political interest, and the second-level digital divide in political Internet use. Journal of Information Technology \& Politics, 7(1), 22-35. https://doi.org/10.1080/19331680903109402

Nam, Taewoo., \& Stromer-Galley, Jennifer. (2012). The democratic divide in the 2008 U.S. presidential election. Journal of Information Technology \& Politics, 9(2), 133-149.

Nassar, Islam., Hayajneh, Jamal \& Almsafir, M. K. H. (2013). Relation between social network and da'wah to Islam: A case study on Jordanian students. International Journal on Islamic Applications in Computer Science and Technology, 1(1), 9-18. Retrieved from http://www.sign-ific-ance.co.uk/index.php/IJASAT/article/view/487

National Cyber Security Alliance. (2003). Past and present danger: In-home study on broadband security among American consumers. Available: http://www.staysafeonline.info/press/060403.pdf

Norris, Pippa. (2001). Digital divide: Civic engagement, information poverty, and the Internet worldwide. Cambridge, England: Cambridge University Press. https://doi.org/10.1017/CBO9781139164887

O'Byrne, Darren. (2003). The dimensions of global citizenship: Political identity beyond the nation state. London, England: Frank Cass. 
Ribble, Mike. \& Bailey, Gerald. (2006). Digital Citizenship at All Grade Levels. Learning \& Leading with Technology. ISTE. Retrieved April 12, 2017 from: http://www.whyville.net/press/L_LMar06Whyville.pdf.

Ryan, Vernon., Agnitsch, Kerry., Zhao, Lijun., \& Mullick, Rehan. (2005). Making sense of voluntary participation: a theoretical synthesis'. Rural Sociology, 70, 287-313. https://doi.org/10.1526/0036011054831198.

Shelley, Mack., Thrane, Lisa., \& Shulman, Stuart. (2006). Lost in cyberspace: Barriers to bridging the digital divide in e-politics. International Journal of Internet and Enterprise Management, 4, 228-243. https://doi.org/10.1504/IJIEM.2006.010916

Steinberger, Peter. (1984). Urban politics and communality. Urban Affairs Quarterly, 20(1), 4-21. https://doi.org/10.1177/004208168402000102

Swidan, Andraws., Al-Shalabi, Hasan., Jwaifell, Mustafa., Awajan, Arafat., \& Alrabea, Alrabea. (2013). The intensity and the factors affecting the use of social network sites among the students of Jordanian universities. International Journal of Computer Science Issues, 10(1), 492-498.

Tawalbe, Hadi. (2017). Digital Citizenship in the National Civic Education Textbook: An Analytical Study. The Jordanian Journal of Educational Sciences, 13(3), 291-208.

Thrane, Lisa., Shulman, Stuart., Shelley, Mack., Beisser, Saly., \& Larson, Teresa. (2005). Does computer training translate to e-political empowerment among Midwestern senior citizens? In B. Jaeger (Ed.), Young Technologies in Old Hands-An International View on Senior Citizens' Utilization of ICT (Copenhagen, Denmark: DJØF Publishing, 2005), $159-173$

Vilenchik, Neta. (2017). Alternative citizenship models: Contextualizing new media and the new "good citizen", New Media \& Society, 19(11), 1887-1903. https://doi.org/10.1177/1461444817713742.

Vilenchik, Neta., \& Thorson, Kjerstin. (2015). Good citizenship as a frame contest: Kony2012, memes, and critiques of the networked citizen, new media \& society, 18(9), 1993-2011. https://doi.org/10.1177/1461444815575311.

Villazor, Rose. (2010). "Sanctuary cities" and local citizenship. Fordham Urban Law Journal, 37(2), 573-598.

Wellman, Barry., Haase, Anabel., Witte, James., \& Hampton, Keith. (2001). Does the Internet increase, decreases, or supplement social capital? Social networks, participation, and community commitment. American Behavioral Scientist, 45, 436-455. https://doi.org/10.1177/00027640121957286 


\section{Appendix}

Appendix 1. Digital Citizenship Quiz:

\begin{tabular}{|c|c|c|}
\hline Elements & Questions and Statements & Answers \\
\hline $\begin{array}{l}\text { Digital Etiquette } \\
\text { (Manners) }\end{array}$ & $\begin{array}{l}\text { Having your cell phone turned on } \\
\text { during university hours is }\end{array}$ & $\begin{array}{l}\text { a bad idea because it } \\
\text { disturbs others }\end{array}$ \\
\hline $\begin{array}{l}\text { Digital } \\
\text { Communication } \\
\text { (Messages) }\end{array}$ & $\begin{array}{l}\text { How many people should you have } \\
\text { in your messenger Buddy List? }\end{array}$ & $\begin{array}{l}\text { only close friends and } \\
\text { family }\end{array}$ \\
\hline $\begin{array}{l}\text { Digital Education } \\
\text { (Learning) }\end{array}$ & $\begin{array}{l}\text { When learning about technology in } \\
\text { university, it is important for you to } \\
\text { know }\end{array}$ & $\begin{array}{l}\text { what different } \\
\text { technologies are and how } \\
\text { they are used }\end{array}$ \\
\hline $\begin{array}{l}\text { Digital Access } \\
\text { (Inclusion) }\end{array}$ & Students with disabilities & $\begin{array}{l}\text { should have the same } \\
\text { opportunities as others to } \\
\text { use technology }\end{array}$ \\
\hline $\begin{array}{l}\text { Digital Commerce } \\
\text { (Business) }\end{array}$ & $\begin{array}{l}\text { If your parents allow you to buy } \\
\text { things on the Internet, you should } \\
\text { protect yourself by }\end{array}$ & $\begin{array}{l}\text { checking to see if the site } \\
\text { is safe and secure }\end{array}$ \\
\hline $\begin{array}{l}\text { Digital Responsibility } \\
\text { (Trust) }\end{array}$ & $\begin{array}{l}\text { When using graphics and text from } \\
\text { the Internet, you should }\end{array}$ & $\begin{array}{l}\text { give credit to the author } \\
\text { of the information in the } \\
\text { project }\end{array}$ \\
\hline $\begin{array}{l}\text { Digital Rights } \\
\text { (Privileges) }\end{array}$ & When using technology, you should & $\begin{array}{l}\text { ask teachers and parents } \\
\text { about what can be done }\end{array}$ \\
\hline $\begin{array}{l}\text { Digital Safety } \\
\text { (Protection) }\end{array}$ & $\begin{array}{l}\text { How do you work with technology } \\
\text { (e.g., sitting, laying, and stooping at } \\
\text { the desk, floor, or sofa): }\end{array}$ & $\begin{array}{l}\text { is important because poor } \\
\text { posture can cause } \\
\text { physical problems later in } \\
\text { life }\end{array}$ \\
\hline $\begin{array}{l}\text { Digital Security } \\
\text { (Self-Protection) }\end{array}$ & $\begin{array}{l}\text { When dealing with people online, } \\
\text { giving personal information is }\end{array}$ & $\begin{array}{l}\text { never a good idea, no } \\
\text { matter the reason }\end{array}$ \\
\hline
\end{tabular}




\section{Copyright Disclaimer}

Copyright for this article is retained by the author(s), with first publication rights granted to the journal.

This is an open-access article distributed under the terms and conditions of the Creative Commons Attribution license (http://creativecommons.org/licenses/by/3.0/). 